\title{
PENGGUNAAN MODEL PEMBELAJARAN JIGSAW UNTUK MENINGKATKAN HASIL BELAJAR SIFAT-SIFAT BANGUN DATAR DI SEKOLAH DASAR
}

\author{
Oleh : Syafri Ahmad \\ Email: syafriahmad95@yahoo.co.id \\ FIP Universitas Negeri Padang
}

\begin{abstract}
This research was conducted as the teacher had not yet used group dynamics in teaching the characteristics of shapes topics. This had made the learning process became teachercentered and the students' learning achievement got low. The purpose of this research was to describe the improvement of the students' learning achievement on the characteristics of shapes topics by using jigsaw cooperative learning model. This reseach was conducted at SDN 03 Pelangai Gadang. The subject of the research was the teacher and the fifth grade students. The result of the research indicated that there was an improvement on the plan, the implementation of the plan and the students' learning achievement. This result had indicated that the use of jigsaw cooperative learning model could improve the students' learning achievement on the characteristics of shapes topic in the fifth grade of SDN 03 Pelangai Gadang.
\end{abstract}

Keywords: Hasil Belajar, Pembelajaran Kooperatif, Jigsaw, Bangun Datar, Siswa SD

\section{PENDAHULUAN}

Kegiatan yang berkaitan dengan bangun datar baik itu di lingkungan sekolah maupun di rumah. Sebagai contoh ketika siswa menulis di papan tulis yang berbentuk persegi panjang atau ketika siswa bermain di lantai yang ubinnya berbentuk persegi. Kegiatan ini menunjukkan bahwa secara tidak langsung siswa telah mengenal bangun datar.

Pembelajaran konsep bangun datar dengan segala sifat-sifatnya perlu diajarkan mulai dari jenjang Sekolah Dasar (SD) agar dapat menjadi bekal bagi siswa dalam kehidupan seharihari. Selain itu pembelajaran sifat-sifat bangun datar juga dapat melatih dan menumbuhkembangkan cara berpikir logis, kritis dan kreatif dari siswa (Jones \& Mooney, 2003 ; Presmeg, 2006; Kennedy, 2008; Nur 'aeni, 2010).

Agar pembelajaran sifat-sifat bangun datar dapat melatih dan menumbuhkembangkan cara berpikir siswa yang logis, kritis dan kreatif, guru harus bisa menciptakan proses pembelajaran yang dapat mengembangkan kompetensi siswa. Salah satu cara untuk menciptakan proses pembelajaran yang dapat menarik minat siswa adalah dengan menggunakan model pembelajaran yang bervariasi serta sesuai dengan karakteristik materi pembelajaran. Penggunaan model pembelajaran yang tepat akan meningkatkan kualitas proses pembelajaran sehingga dapat meningkatkan hasil belajar siswa.

Berdasarkan hasil observasi yang telah dilakukan di SDN 03 Pelangai Gadang kelas V pada tanggal 13 November 2013 guru dalam mengajarkan materi sifat-sifat bangun datar tidak memanfaatkan dinamika kelompok seperti membelajarkan siswa dalam kelompok ahli yang bertugas menemukan sifat-sifat bangun datar melainkan guru mengajar dengan berceramah di depan kelas. Pada hal di kelas V ini mereka sudah bisa belajar dalam kelompok seperti yang dijelaskan oleh Harun (2014) bahwa siswa kelas V mereka telah menyadari diri sendiri dan senang belajar dalam kelompok dari pada bekerja sendiri saja. Sebagai akibat perlakuan guru yang belum memanfaatkan dinamika kelompok ini menyebabkan pembelajaran di dalam kelas terasa monoton dan lebih terpusat kepada guru (teacher centered), akibatnya pembelajaran sifat-sifat bangun datar menjadi pembelajaran yang tidak 
menarik, pemahaman siswa rendah, kurang termotivasi dan akhirnya nilai hasil belajar siswa menjadi rendah.

Berdasarkan data yang diambil dari nilai ulangan harian materi sifat-sifat bangun datar dari 16 orang siswa hanya 7 orang siswa atau $47,75 \%$ yang sudah tuntas mencapai nilai KKM yang ditetapkan yaitu 75 dalam mengidentifikasi sifatsifat bangun datar. Sisanya yaitu 9 orang siswa atau $56,25 \%$ belum tuntas mencapai nilai KKM.

Variasi model pembelajaran yang bisa digunakan untuk mengajarkan materi sifat-sifat bangun datar adalah model pembelajaran kooperatif tipe jigsaw. "Model pembelajaran kooperatif tipe jigsaw dikembangkan oleh Elliot Aronson dan rekan-rekannya, dalam model pembelajaran ini para siswa belajar di dalam tim yang heterogen" (Slavin, 2011). Sedangkan Menurut Rusman (2011) "pembelajaran kooperatif tipe jigsaw merupakan belajar kooperatif dengan cara siswa belajar dalam kelompok kecil yang terdiri dari empat sampai enam orang secara heterogen dan siswa berkerjasama saling ketergantungan positif dan bertanggung jawab secara positif dan bertanggung jawab secara mandiri”. Lebih lanjut Slavin (2011) mengemukakan langkah-langkah model pembelajaran kooperatif tipe jigsaw sebagai berikut : (1). Membagi siswa ke dalam tim, yaitu membagi para siswa ke dalam tim heterogen yang terdiri dari 4 - 5 anggota, (2). Membagi siswa kedalam kelompok ahli, (3). Membaca, para siswa menerima topik ahli dan membaca materi yang diminta untuk menemukan informasi, (4). Diskusi kelompok ahli, para siswa dengan keahlian yang sama bertemu untuk mendiskusikannya dalam kelompok-kelompok ahli, (5). Laporan tim. Para ahli kembali kedalam kelompok asal mereka masing-masing untuk mengajari topik - topik mereka kepada teman satu timnya,(6). Tes. Para siswa mengerjakan kuis kuis individual yang mencakup semua topic, dan (7). Rekognisi tim. Penghitungan skor tim.

Model pembelajaran kooperatif tipe jigsaw ini, guru lebih berperan sebagai fasilitator yang berfungsi sebagai jembatan penghubung ke arah pemahaman yang lebih tinggi, dengan catatan siswa sendiri. Guru tidak hanya memberi pengetahuan kepada siswa, tetapi juga harus membangun pengetahuan dalam pikirannya. Siswa mempunyai kesempatan untuk mendapatkan pengalaman langsung dalam menemukan dan menerapkan ide-ide mereka sendiri. Pembelajaran kooperatif tidak sama dengan sekedar belajar dalam kelompok. Pelaksanaan model pembelajaran kooperatif dengan benar akan memungkinkan guru mengelola kelas dengan efektif. Dalam pembelajaran kooperatif proses pembelajaran tidak hanya dari guru kepada siswa tetapi juga pembelajaran oleh rekan sebaya yang akan lebih efektif daripada pembelajaran oleh guru saja.

Lei ( dalam Rusman, 2011) menyatakan "bahwa tipe jigsaw merupakan salah satu model pembelajaran kooperatif yang fleksibel". Berdasarkan riset yang telah dilakukannya secara konsisten menunjukkan bahwa siswa yang terlibat di dalam pembelajaran kooperatif tipe jigsaw memperoleh prestasi yang lebih baik, mempunyai sikap yang lebih baik dan lebih positif terhadap pembelajaran, disamping saling menghargai perbedaan dan pendapat orang lain. Senada dengan pendapat tersebut Nurhadi dkk (2004) mengemukakan beberapa keunggulan model pembelajaran tipe jigsaw yaitu: (1). Mengembangkan kegembiraan belajar yang sejati, (2). Memungkinkan para siswa saling belajar mengenai sikap, keterampilan, informasi, perilaku sosial, dan pandangan, (3). Meningkatkan keterampilan metakognitif, (4). Meningkatkan kepekaan dan kesetiakawanan sosial, (5). Meningkatkan sikap positif terhadap belajar dan pengalaman belajar, (6). Meningkatkan kemampuan berpikir divergen atau berpikir kreatif, (7). Meningkatkan rasa harga diri (self - esteem) dan penerimaan diri (selfacceptance), (8). Meningkatkan hubungan positif antara siswa dengan guru dan personel sekolah lainnya. 
Berdasarkan uraian di atas, tujuan penulisan artikel ini adalah untuk mendeskripsikan bentuk rancangan pelaksanaan pembelajaran, bentuk pelaksanaan pembelajaran, dan peningkatan hasil belajar sifat-sifat bangun datar dengan model pembelajaran kooperatif tipe jigsaw bagi siswa kelas V SDN 03 Pelangai Gadang Pesisir Selatan.

\section{METODOLOGI PENELITIAN}

Penelitian ini dilaksanakan di Sekolah Dasar Negeri No. 03 Pelangai Gadang Kecamatan Ranah Pesisir Kabupaten Pesisir Selatan. Yang menjadi subjek penelitian adalah siswa kelas $\mathrm{V}$ yang terdaftar pada semester II tahun ajaran 2013/2014 dengan jumlah 16 orang. Penelitian ini terdiri dari 2 siklus, masing - masing siklus terdiri dari 2 kali pertemuan dengan alokasi waktu 1 kali pertemuan ( $3 \times 35$ menit ). Pendekatan yang digunakan adalah pendekatan kualitatif dan pendekatan kuantitatif sedangkan jenis penelitiannya adalah penelitian tindakan kelas (clasroom action research).

Sumber data penelitian diperoleh dari proses kegiatan pembelajaran sifat- sifat bangun datar dengan menggunakan model pembelajaran kooperatif tipe jigsaw di kelas V SD. Teknik pengumpulan data : observasi dan tes. Instrumen yang digunakan adalah lembar observasi dan lembaran tes. Dalam penelitian ini peneliti menggunakan model yang dikembangkan oleh Kemmis dan MC Taggart (1988) yang terdiri dari perencanaan, tindakan, pengamatan dan refleksi.

Data yang diperoleh dalam penelitian dianalisis dengan menggunakan analisis data kualitatif yakni analisa data dimulai dengan menelaah sejak pengumpulan data sampai seluruh data terkumpul. Tahap analisis tersebut antara lain : (1). Menelaah data yang terkumpul, (2). Reduksi data, meliputi pengkategorian dan pengklasifikasian, (3). Menyajikan data, dilakukan dengan cara mengorganisasikan data yang telah direduksi.

Analisis data dilakukan terhadap data yang telah direduksi baik data perencanaan, pelaksanaan maupun data evaluasi. Sedangkan model analisis kuantitatif yaitu dilakukan terhadap hasil belajar siswa dengan menggunakan pendekatan persentase dengan rumus sebagai berikut :

$$
\mathrm{P}=\mathrm{F} X 100 \% \mathrm{~N}
$$

Keterangan :

$$
\begin{aligned}
& \mathrm{P}=\text { Persentase } \\
& \mathrm{F}=\text { Frekuensi responden } \\
& \mathrm{N}=\text { Jumlah responden }
\end{aligned}
$$

\section{HASIL PENELITIAN DAN PEMBAHASAN Hasil Penelitian}

Siklus I berlangsung 2 kali pertemuan, pertemuan I dilaksanakan pada hari Rabu tanggal 14 Mei 2014, sedangkan pertemuan II dilaksanakan pada hari Jum'at tanggal 16 Mei 2014 dengan rinciannya dimulai dari perencanaan, pelaksanaan, pengamatan dan refleksi.

\section{Perencanaan}

Materi pembelajaran yang dilaksanakan pada pertemuan pertama ini adalah sifat - sifat bangun datar yan meliputi sifat - sifat bangun datar persegi, sifat - sifat bangun datar persegi panjang, sifat - sifat bangun datar segitiga, dan sifat sifat bangun datar trapesium dengan alokasi waktu 2 x 35 menit (1x pertemuan). Penyusunan perencanaan berdasarkan Kurikulum Tingkat Satuan Pendidikan (KTSP) yang dituangkan dalam seperangkat Rencana Pelaksanaan Pembelajaran (RPP). RPP memuat (1). Satuan Pendidikan, (2). Mata Pelajaran, (3). Kelas/Semester, (4). Alokasi Waktu, (5). Standar Kompetensi, (6). Kompetensi Dasar, (7). Indikator, (8). Tujuan Pembelajaran (9). Materi Pokok, (10). Metode/Model Pembelajaran, (11). Media dan Sumber Belajar, (12). Kegiatan Pembelajaran, (13). Penilaian

RPP pada siklus I initerdiri dari $2 \mathrm{x}$ pertemuan yaitu pertemuan I dan II, setiap pertemuan direncanakan siswa akan mengikuti proses pembelajaran dalam tiga tahap kegiatan 
yaitu kegiatan awal, kegiatan inti dan kegiatan akhir. Pada kegiatan inti siswa akan melaksanakan kegiatan pembelajaran dengan langkah-langkah model pembelajaran kooperatif tipe jigsaw, dimana langkah-langkah yang dipakai pada RPP ini adalah langkah-langkah model pembelajaran kooperatif tipe jigsaw yang dikemukakan oleh Slavin yang terdiri dari 7 langkah yaitu : (1). Membagi siswa ke dalam tim heterogen yang terdiri dari $4-6$ orang, (2). Membagi siswa ke dalam kelompok ahli, (3). Membaca, (4). Diskusi kelompok ahli, (5). Laporan tim, (6). Tes, (7). Rekognisi tim. Pada pertemuan I direncanakan akan dilaksanakan 4 langkah model pembelajaran kooperatif tipe jigsaw yaitu langkah $1-4$, sedangkan langkah $5-7$ akan dilaksanakan pada pertemuan II. Penilaian direncanakan berlangsung pada saat dan diakhir proses pembelajaran yang mencakup tiga ranah yaitu ranah kognitif, ranah afektif dan ranah psikomotor.

Untuk mengamati proses pembelajaran berlangsung peneliti menyiapkan lembar observasi yang akan diisi oleh observer yaitu guru kelas V. Lembar observasi terdiri dari lembar observasi RPP, lembar observasi aktivitas guru dan lembar observasi aktivitas siswa.

\section{Pelaksanaan}

Pertemuan I dilaksanakan pada hari Rabu tanggal 14 Mei 2014 yang dimulai pukul 10.20 11.30 WIB. Pelaksanaan pembelajarannya sebagai berikut :

\section{Kegiatan Awal}

Terdiri dari: guru mengucapkan salam, menyiapkan kondisi kelas untuk belajar yaitu memeriksa kesiapan dan kehadiran siswa serta menyiapkan media/ alat peraga, berdoa, guru memberikan appersepsi dengan bertanya jawab tentang jenis-jenis bangun datar serta contoh benda yang berbentuk bangun datar yang ada di dalam ruangan kelas, guru menyampaikan tujuan pembelajaran.

\section{Kegiatan Inti}

Pada kegiatan inti peneliti melanjutkan kegiatan pembelajaran dengan menggunakan langkah - langkah model pembelajaran kooperatif tipe jigsaw dimana pada pertemuan I ini dilaksanakan langkah $1-4$ yaitu sebagai berikut : 1). Membagi siswa ke dalam tim ( kelompok asal ). Membagi siswa ke dalam tim heterogen yang terdiri 4 orang siswa setiap kelompok, 2). Membagi siswa ke dalam kelompok ahli. Membentuk kelompok baru yang berasal dari kelompok asal berbeda, 3). Membaca. Guru membagikan topik ahli,4). Diskusi kelompok ahli. Siswa yang mendapat topik sama berdiskusi dalam kelompok ahli.

\section{Kegiatan Akhir}

Kegiatan penutup dari pertemuan pertama ini adalah guru menjelaskan kegiatan yang akan dilakukan siswa pada pertemuan selanjutnya serta menutup pembelajaran dengan mengajak siswa bersyukur membaca hamdallah.

Pertemuan II dilaksanakan pada hari Jum'at tanggal 16 Mei 2014 dengan alokasi waktu 2 x 35 menit yang dimulai pukul $07.30-08.40$ WIB. Pelaksanaan pembelajarannya adalah sebagai berikut :

\section{Kegiatan awal}

Mengawali kegiatan pembelajaran, guru mengucapkan salam,guru kemudian menyiapkan kondisi kelas dan mengabsen siswa, guru memberikan appersepsi tentang kegiatan yang telah dilakukan siswa pada pertemuan sebelumnya,guru menyampaikan tujuan pembelajaran.

\section{Kegiatan inti}

Kegiatan pembelajaran pada kegiatan inti pertemuan II ini merupakan lanjutan langkah - langkah model pembelajaran kooperatif tipe jigsaw pada pertemuan sebelumnya yaitu langkah 5 -7. Berikut ini adalah penjelasannya :5). Laporan tim. Melaporkan hasil diskusi pada kelompok asal, 6). Tes. Siswa mengerjakan soal tes, 7). Rekognisi tim. Penghitungan skor tim.

\section{Kegiatan akhir}

Kegiatan pembelajaran yang dilakukan pada kegiatan akhir adalah guru memberikan siswa penjelasan tentang rangkuman hasil proses pembelajaran. Guru membimbing siswa membuat 
kesimpulan pembelajaran. Selanjutnya guru memberikan pekerjaan rumah untuk siswa sesuai materi pembelajaran yang telah diajarkan.Terakhir guru menutup pembelajaran dengan mengajak siswa bersyukur membaca hamdallah.

\section{Pengamatan}

Hasil observasi pada siklus I :a) RPP :
80,36 \% dengan kategori baik, b) Pelaksanaan terdiri dari penilaian aktivitas guru : 73,96\% dengan kualifikasi cukup (C) dan aktivitas siswa : $70,84 \%$ kategori cukup (C). c). Hasil belajar:memperoleh nilai rata - rata 68,1 dengan kategori kurang.

Tabel 1.1 rekapitulasi hasil belajar siswa siklus I

\begin{tabular}{|c|c|c|c|c|c|c|c|c|}
\hline \multirow{2}{*}{ No } & \multirow[b]{2}{*}{ Nama Siswa } & \multicolumn{3}{|c|}{ Jenis Penilaian } & \multirow{2}{*}{ Jumlah Nilai } & \multirow{2}{*}{ Rata-rata } & \multicolumn{2}{|c|}{ Ketuntasan } \\
\hline & & Kognitif & Afektif & Psikomotor & & & Tuntas & Belum Tuntas \\
\hline 1 & DJM & 9 & 7 & 83,3 & 248,3 & 82,8 & $\mathrm{v}$ & \\
\hline 2 & IF & 8 & 58,3 & 66,7 & 205 & 68,3 & & $\mathrm{~V}$ \\
\hline 3 & FRH & 9 & 7 & 91,7 & 256,7 & 85,6 & $\mathrm{v}$ & \\
\hline 4 & MKS & 8 & 83,3 & 83,3 & 246,6 & 82,2 & $\mathrm{~V}$ & \\
\hline 5 & DCA & 9 & 7 & 7 & 240 & 80 & $\mathrm{~V}$ & \\
\hline 6 & RW & 8 & 100 & 83,3 & 263,3 & 87,8 & $\mathrm{~V}$ & \\
\hline 7 & $\mathrm{AD}$ & 8 & 58,3 & 7 & 213,3 & 71,1 & & $\mathrm{v}$ \\
\hline 8 & FL & 6 & 66,7 & 66,7 & 193,4 & 64,5 & & $\mathrm{v}$ \\
\hline 9 & $\mathrm{IZ}$ & 8 & 5 & 41,6 & 171,6 & 57,2 & & $\mathrm{v}$ \\
\hline 10 & SWD & 8 & 66,7 & 66,7 & 213,4 & 71,1 & & $\mathrm{v}$ \\
\hline 11 & RJW & 6 & 41,6 & 41,6 & 143,2 & 47,7 & & $\mathrm{~V}$ \\
\hline 12 & AWD & 7 & 58,3 & 5 & 178,3 & 59,4 & & $\mathrm{~V}$ \\
\hline 13 & RRA & 5 & 66,7 & 66,7 & 183,4 & 61,1 & & $\mathrm{~V}$ \\
\hline 14 & $\mathrm{RG}$ & 5 & 7 & 66,7 & 191,7 & 63,9 & & $\mathrm{~V}$ \\
\hline 15 & AJH & 7 & 66,7 & 5 & 186,7 & 62,2 & & $\mathrm{~V}$ \\
\hline \multirow[t]{3}{*}{16} & $\mathrm{CD}$ & 5 & 5 & 33,3 & 133,3 & 44,4 & & $\mathrm{~V}$ \\
\hline & Jumlah & 1160 & 1066,8 & 1041,7 & 3268,2 & 1089,3 & \multicolumn{2}{|c|}{\begin{tabular}{|l|l|}
$31,25 \%$ & $68,75 \%$ \\
\end{tabular}} \\
\hline & Rata - rata & 72,5 & 66,7 & 65,1 & 204,2 & 68,1 & & \\
\hline
\end{tabular}

\section{Refleksi}

Refleksi dilakukan secara kolaboratif antara peneliti dengan teman sejawat yang telah melakukan pengamatan pada saat proses pembelajaran. Hasil refleksi akan dimanfaatkan sebagai masukan pada tindakan selanjutnya. Refleksi tindakan siklus I adalah sebagai berikut:

\section{RPP}

1). Pengorganisasian materi ajar belum sesuai dengan alokasi waktu. Cakupan materi yang diberikan juga kurang luas, 2). Langkah-langkah pembelajaran tidak sesuai dengan alokasi waktu.3). Soal yang diberikan guru tidak dalam bentuk yang beragamserta tidak dilengkapi dengan pedoman penskoran.

\section{Pelaksanaan}

Aktivitas guru

a). Pada langkah membagi siswa ke dalam kelompok ahli, guru tidak memberi nama kelompok ahli berdasarkan materi yang akan dibahas kelompok ahli tersebut, b). Pada saat dikusi kelompok ahli guru kurang mengamati dan membimbing siswa dalam berdiskusi. Hal ini mengakibatkan siswa tidak tertib dalam berdiskusi., c). Pada langkah laporan tim, guru tidak meminta setiap kelompok untuk memastikan kesiapan teman satu timnya menghadapi tes yang akan diberikan, sehingga banyak siswa yang tidak siap dalam menghadapi tes, d). Pada saat tes guru tidak memberikan 
rentang waktu pada siswa untuk mengerjakan soal. Guru juga tidak meminta siswa mengerjakan soal sesuai waktu yang ditentukan.e). Pada langkah rekognisi tim, guru tidak memberikan pujian kepada siswa yang mendapat nilai tertinggi.

Aktivitas siswa

a). Pada langkah membagi siswa dalam kelompok ahli, siswa tidak menyimak guru memberi nama kelompok ahli karena guru juga tidak memberi nama kelompok ahli. Siswa juga kurang mendengarkan guru menjelaskan tugas siswa dalam kelompok ahli.b). Pada langkah membaca, siswa kurang bertanggung jawab mempelajari bagian materi yang sudah ditugaskan, c). Pada saat diskusi kelompok ahli, siswa tidak berdiskusi dengan tertib.Diharapkan guru dapat membimbing siswanya dalam berdiskusi, d).Pada saat laporan tim, siswa tidak memastikan kesiapan teman satu timnya menghadapi tes, sehingga banyak siswa yang tidak siap menghadapi tes, d).Pada saat presentasi hanya beberapa kelompok yang mau maju mempresentasikan hasil diskusinya ke depan kelas, hal ini disebabkan karena siswa tidak terbiasa berbicara di depan kelas sehingga mereka malu untuk berbicara di depan kelas, e). Pada langkah tes, siswa tidak mendengarkan penjelasan guru tentang rentang waktu mengerjakan soal. Siswa juga tidak mengerjakan soal sesuai waktu yang

ditentukan, f).Pada langkah rekognisi tim, siswa yang mendapat nilai tertinggi tidak mendapatkan pujian dari guru.

\section{Hasil belajar}

Hasil belajar siswa pada siklus I ini terdiri dari penilaian kognitif, afektif dan psikomotor dengan nilai rata-rata 68,1 . Nilai ini tidak mencapai nilai KKM yang telah ditentukan yaitu 75 .

Berdasarkan hasil pengamatan secara keseluruhan, maka tujuan pembelajaran pada pembelajaran siklus I belum tercapai dengan baik. Untuk itu perlu diadakan lagi upaya peningkatan pada proses pembelajaran siklus II dengan memperhatikan kendala-kendala yang dihadapi pada siklus I.
Pembelajaran pada siklus II pada dasarnya sama dengan siklus I. Pelaksanaan pembelajaran pada siklus II juga terdiri dari $2 \mathrm{x}$ pertemuan.

\section{Perencanaan}

Materi pembelajaran yang dilaksanakan pada siklus II ini adalah sifat- sifat bangun datar yan meliputi sifat-sifat bangun datar persegi, sifatsifat bangun datar persegi panjang, sifat-sifat bangun datar segitiga, dan sifat-sifat bangun datar trapesium dengan alokasi waktu $3 \times 35$ menit ( $1 \times$ pertemuan ). Penyusunan perencanan berdasarkan Kurikulum Tingkat Satuan Pendidikan ( KTSP ) yang dituangkan dalam seperangkat Rencana Pelaksanaan Pembelajaran ( RPP ). Standar kompetensi yang diterapkan dalam penelitian ini adalah memahami sifat- sifat bangun dan hubungan antarbangun. Kompetensi dasar yang harus dikuasai siswa adalah mengidentifikasi sifat-sifat bangun datar dengan indikatornya yaitu : (1). Mengidentifikasi sifat-sifat bangun datar persegi, (2). Mengidentifikasi sifat - sifat bangun datar persegi panjang,

Mengidentifikasi sifat-sifat bangun datar segitiga, (4). Mengidentifikasi sifat-sifat bangun datar trapesium.

RPP memuat (1). Satuan Pendidikan, (2). Mata Pelajaran, (3). Kelas/Semester, (4). Alokasi Waktu, (5). Standar Kompetensi, (6). Kompetensi Dasar, (7). Indikator, (8). Tujuan Pembelajaran (9). Materi Pokok, (10). Metode / Model Pembelajaran, (11).Media dan Sumber Belajar, (12). Kegiatan Pembelajaran, (13). Penilaian .

RPP ini juga terdiri dari $2 \times$ pertemuan yaitu pertemuan I dan II, setiap pertemuan direncanakan siswa akan mengikuti proses pembelajaran dalam tiga tahap kegiatan yaitu kegiatan awal, kegiatan inti dan kegiatan akhir. Pada kegiatan inti siswa akan melaksanakan kegiatan pembelajaran dengan langkah-langkah model pembelajaran kooperatif tipe jigsaw, dimana langkah-langkah yang dipakai pada RPP ini adalah langkah-langkah model pembelajaran kooperatif tipe jigsaw yang dikemukakan oleh Slavin yang terdiri dari 7 langkah yaitu : (1). 
Membagi siswa ke dalam tim heterogen yang terdiri dari $4-6$ orang, (2). Membagi siswa ke dalam kelompok ahli, (3). Membaca, (4). Diskusi kelompok ahli, (5). Laporan tim, (6). Tes, (7). Rekognisi tim. Pada pertemuan I direncanakan akan dilaksanakan 4 langkah model pembelajaran kooperatif tipe jigsaw yaitu langkah $1-4$, sedangkan langkah $5-7$ akan dilaksanakan pada pertemuan II. Penilaian direncanakan berlangsung pada saat dan diakhir proses pembelajaran yang mencakup tiga ranah yaitu ranah kognitif, ranah afektif dan ranah psikomotor.

\section{Pelaksanaan}

Pelaksanaan pembelajaran sifat - sifat bangun datar dengan menggunakan model pembelajaran kooperatif tipe jigsaw di kelas $\mathrm{V}$ SDN 03 Pelangai Gadang Pesisir Selatan, pertemuan I dilaksanakan pada hari Rabu tanggal 21 Mei 2014 yang dimulai pukul 10.20 - 12.05 WIB. Pelaksanaan pembelajarannya sebagai berikut :

\section{Kegiatan Awal}

Kegiatan awal pada siklus II terdi dari : mengucapkan salam, menyiapkan kondisi kelas untuk belajar yaitu memeriksa kesiapan dan kehadiran siswa serta menyiapkan media/ alat peraga, guru meminta seluruh siswa untuk berdoa. Selanjutnya guru memberikan appersepsi dengan bertanya jawab tentang materi yang telah dipelajarinya minggu lalu yaitu jenis-jenis bangun datar serta contoh benda yang berbentuk bangun datar yang ada di dalam ruangan kelas. Pada pertemuan kali ini sudah banyak siswa yang mau menjawab pertanyaan guru, sehingga pembelajaran lebih aktif daripada pertemuan sebelumnya.Setelah memberikan appersepsi, guru menyampaikan tujuan pembelajaran.

\section{Kegiatan Inti}

Pada kegiatan inti siklus II peneliti melanjutkan kegiatan pembelajaran dengan menggunakan langkah-langkah model pembelajaran kooperatif tipe jigsaw, sama dengan siklus I dimana pada pertemuan I siklus II ini dilaksanakan langkah $1-4$ yaitu sebagai berikut :
1). Membagi siswa ke dalam tim ( kelompok asal ). Siswa dibagi ke dalam tim heterogen yang beranggotakan 4 orang, 2). Membagi siswa ke dalam kelompok ahli. Guru membentuk kelompok baru yang anggotanya berasal dari tim yang berbeda, 3). Membaca. Guru membagikan topik ahli,4). Diskusi kelompok ahli. Siswa yang mendapat topik sama berdiskusi dalam kelompok ahli.

\section{Kegiatan Akhir}

Sebelum menutup kegiatan pertemuan pertama ini adalah guru menjelaskan kegiatan yang akan dilakukan siswa pada pertemuan selanjutnya serta menutup pembelajaran dengan mengajak siswa bersyukur membaca hamdallah.

Pertemuan II dilaksanakan pada hari Jum'at tanggal 23 Mei 2014 dengan alokasi waktu 3 x 35 menit yang dimulai pukul $07.30-09.15$ WIB. Pelaksanaan pembelajarannya adalah sebagai berikut :

\section{Kegiatan Awal}

Guru mengucapkan salam ,guru menyiapkan kondisi kelas dan mengabsen siswa, guru memberikan appersepsi tentang kegiatan yang telah dilakukan siswa pada pertemuan sebelumnya, guru menyampaikan tujuan pembelajaran.

\section{Kegiatan Inti}

Kegiatan pembelajaran pada kegiatan inti pertemuan II ini merupakan lanjutan langkah-langkah model pembelajaran kooperatif tipe jigsaw pada pertemuan sebelumnya yaitu langkah 5 -7. Berikut ini adalah penjelasannya : 5). Laporan tim. Siswa kembali ke kelompok asal melaporkan hasil diskusi, 6). Tes. Siswa mengerjakan soal tes, 7). Rekognisi tim. Penghitungan skor tim.

\section{Pengamatan}

Hasil observasi pada siklus I :a) RPP : $89,28 \%$ dengan kategori baik, b) Pelaksanaan terdiri dari penilaian aktivitas guru : 96,88\% dengan kualifikasi sangat baikdan aktivitas siswa : $96,88 \%$ kategori sangat baik. c). Hasil belajar:memperoleh nilai rata-rata 86,1 dengan kategori baik. 
Tabel 1.2 Rekapitulasi hasil belajar siswa siklus II

\begin{tabular}{|c|c|c|c|c|c|c|c|c|}
\hline \multirow{2}{*}{ No } & \multirow{2}{*}{$\begin{array}{l}\text { Nama } \\
\text { Siswa }\end{array}$} & \multicolumn{3}{|c|}{ Jenis Penilaian } & \multirow{2}{*}{$\begin{array}{c}\text { Jumlah } \\
\text { Nilai }\end{array}$} & \multirow{2}{*}{ Rata-rata } & \multicolumn{2}{|r|}{ Ketuntasan } \\
\hline & & Kognitif & Afektif & Psikomotor & & & Tuntas & Belum Tuntas \\
\hline 1 & DJM & 100 & 91,7 & 100 & 291,7 & 97,2 & $\mathrm{v}$ & \\
\hline 2 & IF & 9 & 83,3 & 91,7 & 265 & 88,3 & $\mathrm{v}$ & \\
\hline 3 & FRH & 100 & 100 & 100 & 300 & 100 & $\mathrm{v}$ & \\
\hline 4 & MKS & 9 & 91,7 & 91,7 & 273,4 & 91,1 & $\mathrm{v}$ & \\
\hline 5 & DCA & 9 & 91,7 & 83,3 & 265 & 88,3 & $\mathrm{v}$ & \\
\hline 6 & RW & 9 & 83,3 & 100 & 273,3 & 91,1 & $\mathrm{v}$ & \\
\hline 7 & $\mathrm{AD}$ & 9 & 83,3 & 91,7 & 265 & 88,3 & $\mathrm{v}$ & \\
\hline 8 & FL & 8 & 91,7 & 91,7 & 263,4 & 87,8 & $\mathrm{v}$ & \\
\hline 9 & IZ & 8 & 75 & 75 & 230 & 76,7 & $\mathrm{v}$ & \\
\hline 10 & SWD & 8 & 91,7 & 83,3 & 255 & 85 & $\mathrm{v}$ & \\
\hline 11 & RJW & 7 & 83,3 & 83,3 & 236,6 & 78,9 & $\mathrm{v}$ & \\
\hline 12 & AWD & 8 & 75 & 91,7 & 246,7 & 82,2 & $\mathrm{v}$ & \\
\hline 13 & RRA & 8 & 83,3 & 83,3 & 246,6 & 82,2 & $\mathrm{v}$ & \\
\hline 14 & RG & 8 & 91,7 & 83,3 & 255 & 85 & $\mathrm{v}$ & \\
\hline 15 & AJH & 8 & 66,7 & 75 & 221,7 & 73,9 & & $\mathrm{~V}$ \\
\hline 16 & $\mathrm{CD}$ & 8 & 83.3 & 83,3 & 246,6 & 82,2 & $\mathrm{v}$ & \\
\hline & Jumlah & 1360 & 1366,7 & 1408,3 & 4135 & 1378,2 & $93,75 \%$ & $6,25 \%$ \\
\hline & Rata-rata & 8 & 85,42 & 88,02 & 258,4 & 86,1 & & \\
\hline
\end{tabular}

\section{Refleksi}

Refleksi pembelajaran siklus II dilakukan secara kolaboratif antara peneliti dan observer yang telah melakukan pengamatan pada saat proses pembelajaran berlangsung. Berikut ini adalah hasil refleksi siklus II :

\section{RPP}

Dari nilai yang diperoleh yaitu 89,28 \% dapat disimpulkan bahwa perencaan pada siklus II ini terencana dengan baik.

\section{Pelaksanaan}

\section{Aktivitas Guru}

Nilai yang diperoleh adalah 96,88 \% dengan kriteria sangat baik (SB). Aktivitas Siswa Jika dilihat dari perolehan nilai yaitu 96,88 \% maka kriteria taraf keberhasilan penilaian aktivitas siswa siklus II adalah sangat baik (SB).

\section{Hasil Pembahasan}

Hasil belajar siswa pada siklus II ini juga mengalami peningkatan yang sangat memuaskan. Jika dilihat dari rekapitulasi nilai hasil belajar siswa yaitu 86,1 maka nilai ini sudah mencapai
KKM yang telah ditetapkan.

Secara keseluruhan hasil belajar siklus II lebih baik dari siklus I. Jika dilihat dari keseluruhan nilai yang didapat maka tujuan pembelajaran pada siklus II ini sudah terlaksana dengan baik dan peneliti telah berhasil menerapkan model pembelajaran kooperatif tipe jigsaw dalam upaya peningkatan hasil belajar siswa dalam pembelajaran sifat-sifat bangun datar di kelas V SDN 03 Pelangai Gadang Pesisir Selatan.

\section{Permbahasan}

Hasil penelitian pembelajaran sifat-sifat bangun datar dengan menggunakan model pembelajaran kooperatif tipe jigsaw di kelas $\mathrm{V}$ SDN 03

Pelangai Gadang Pesisir Selatan pada siklus I belum tuntas dilihat dari rata-rata nilai yang diperoleh siswa yaitu 68,1 dengan kategori kurang. Nilai tersebut belum mencapai KKM yang telah ditentukan sebelumnya yaitu 75 . Beberapa hal yang menyebabkan hal ini adalah : 
1). Siswa belum terbiasa menggunakan model kooperatif tipe jigsaw sehingga guru kesulitan membagi alokasi waktu. 2). Siswa masih kurang termotivasi dalam pembelajaran sehingga siswa kurang aktif dalam pembelajaran. Berdasarkan uraian tersebut maka perlu adanya peningkatan pembelajaran dengan menggunakan model pembelajaran kooperatif tipe jigsaw pada siklus II.

Hasil belajar pada proses pembelajaran siklus II menggunakan model pembelajaran kooperatif tipe jigsaw mengalami peningkatan menjadi 86,1 dengan kategori baik. Pada pembelajaran siklus II ini penelti menemukan hal - hal sebagai berikut: (1). Siswa sudah mulai memahami langkah-langkah model pembelajaran kooperatif tipe jigsaw sehingga pelaksanaan pembelajaran dapat berjalan dengan baik dan tertib,(2). Sudah banyak siswa yang aktif terlibat dalam proses pembelajaran terutama pada saat berdiskusi, (3). Guru sudah memotivasi siswa sehingga siswa aktif dalam berdiskusi dan tidak ragu-ragu dan malu untuk mengeluarkan pendapat ataupun bertanya. Temuan ini sejalan dengan pendapat Nurhadi (2004) bahwa dengan menerapkan pembelajaran kooperatif tipe jigsaw dapat meningkatkan keaktifan, kreatifitas dan harga diri serta rasa percaya diri siswa dalam proses pembelajaran, dan, (4). Penyajian materi pembelajaran sudah sesuai dengan alokasi waktu yang telah direncanakan dalam RPP. Berdasarkan hasil yang diperoleh pada siklus II maka dapat disimpulkan bahwa penggunaan model pembelajaran kooperatif tipe jigsaw pada pembelajaran sifat-sifat bangun datar dapat meningkatkan hasil belajar siswa kelas V SDN 03 Pelangai Gadang.

\section{SIMPULAN DAN SARAN}

Simpulan dari hasil penelitian ini adalah sebagai berikut : (1). Bentuk rencana pelaksanaan pembelajaran sifat-sifat bangun datar dengan menggunakan model pembelajaran kooperatif tipe jigsaw diawali dengan membagi siswa ke dalam kelompok tim asal, membagi siswa ke dalam kelompok tim ahli, membaca, diskusi kelompok ahli, laporan tim, tes dan rekognisi tim. Penilaian RPP pada siklus I adalah 80,36\% dengan kualifikasi baik dan meningkat pada siklus II menjadi 89,28 \% dengan kualifikasi baik, (2). Pelaksanaan pembelajaran pada aspek aktifitas guru pada siklus I memperoleh hasil penilaian pengamatan $73,96 \%$ dengan kualifikasi cukup dan meningkat pada siklus II menjadi 96, 88 \% dengan kulifikasi sangat baik. Sedangkan pelaksanaan pembelajaran pada aspek aktifitas siswa pada siklus I memperoleh hasil penilaian pengamatan $70,84 \%$ dengan kualifikasi cukup dan meningkat pada siklus II menjadi 96, $88 \%$ dengan kulifikasi sangat baik, dan (3). Pada aspek penilaian hasil belajar siswa pada pembelajaran sifat-sifat bangun datar dengan menggunakan model pembelajaran kooperatif tipe jigsaw di kelas V SDN 03 Pelangai Gadang pada siklus I memperoleh skor 68,1 dengan kulifikasi kurang dan meningkat pada siklus II menjadi 86,1 dengan kualifikasi baik. Hal ini membuktikan bahwa model pembelajaran kooperatif tipe jigsaw dapat meningkatkan hasil belajar siswa khususnya dalam pembelajaran sifat - sifat bangun datar.

Dari simpulan di atas dapat disarankan hal-hal sebagai berikut: (1). Dalam menyusun rancangan pelaksanaan pembelajaran sifat sifat bangun datar di sarankan kepada guru menggunakan langkah-langkah model pembelajran kooperatif tipe jigsaw,(2). Pada pelaksanaan pembelajaran sifat-sifat bangun datar, guru dapat menggunakan model pembelajaran kooperatif tipe jigsaw karena dapat meningkatkan keaktifan dan kreatifitas, serta hasil belajar siswa, dan (3). Untuk meningkatkan hasil belajar siswa pada pembelajaran sifat-sifat bangun datar, guru sekolah dasar diharapakan sebaiknya menggunakan model pembelajaran kooperarif tipe jigsaw. 


\section{DAFTAR PUSTAKA}

Harun, Mardiah. (2014). Membantu anak menguasai Geometri; menumbuhkembangkan kepekaan ruang. Padang : Suka Bina Press

Jones, K. \& Mooney, C. (2003). Making space for geometry in primary mathematics. InI.Thompson (Ed.), Enhancing Primary Mathematics Teaching and Learning (pp3-15). London:Open University Press.

Kemmis, S \& MC Taggart Robbin. ( 1988). The Action Research Planner . Victoria: Deakin University.

Kennedy, L.M, Tipps, S, and Art Johson. 2008. Guiding Children's Learning of Mathematics. U.S.A : Thomson.

Nur'aeni, Epon. 2010. Pengembangan Kemampuan Pemahaman dan Komunikasi Matematis Siswa Sekolah Dasar Melalui Pembelajaran Geometri Berbasis $H$
Teori Van Hiele. Bandung: Disertasi Tidak diterbitkan.

Nurhadi dkk. (2004). Pembelajaran Kontekstual (Contextual Teaching and Learning/CTL) dan Penerapannya Dalam KBK. Malang : Universitas Negeri Malang (UMPRESS).

Presmeg, N. (2006). Research on visualization in learning and teaching mathematics. InA.Gutierrez \& P.Boero (Eds.), Handbook of Research on the Psychology of MathematicsEducation: Past, Present and Future (pp. 205-236). Sense Publishers.

Rusman. (2011). Model-Model Pembelajaran. Jakarta : PT Rajagrafindo

Slavin, Robert E. (2011). Cooperative Learning. Bandung : Nusa Media. 